\title{
Luonto- ja ympäristöalan opetus uudistuu ammatillisessa koulutuksessa
}

Susanna Tauriainen

Opetushallitus, Kumpulantie 3, 00520 Helsinki, susanna.tauriainen@oph.fi

\section{Tiivistelmä}

Luonto- ja ympäristöala on vielä melko nuori ammatillinen ala. Luonto- ja ympäristöalan perustutkintoa on voinut suorittaa vuodesta 2001 lähtien. Luonto- ja ympäristöalalle hakeutuu vuosittain vajaa kaksisataa ensisijaista nuorta hakijaa. Kaiken kaikkiaan alalla aloittaa vajaa neljä sataa nuorta ja aikuista uutta opiskelijaa. Koulutusta tarjoavat noin vajaa kolmekymmentä ammatillista oppilaitosta ympäri Suomea. Tutkinto kouluttaa moniosaajia niin luontomatkailun, maisemanhoidon, luonnosta kerättyjen materiaalien tai ravinteiden tuotteistamiseen sekä ympäristönhoidon pariin. Nykyinen luonto- ja ympäristöalan perustutkinnon suorittaminen kestää kolme vuotta. Näyttötutkintoperusteisessa aikuiskoulutuksessa sen voi suorittaa lyhyemmässäkin ajassa. Luonto- ja ympäristöalan perustutkinto sisältää kolme koulutusohjelmaa. Ne ovat luontoalan, poro- ja luontaistalouden sekä ympäristönhoidon koulutusohjelmat. Luontoalan koulutusohjelmasta valmistuu luontoyrittäjäksi, poro- ja luontaistalouden koulutusohjelmasta puolestaan valmistuu porotalousyrittäjäksi tai luontaistalousyrittäjäksi. Ympäristönhoidon koulutusohjelmasta valmistuvan tutkintonimike on ympäristönhoitaja. Näyttötutkintoperusteisessa koulutuksessa voi ammattiosaamistaan täydentää suorittamalla erä- ja luonto-oppaan, ympäristöhuollon, vesihuoltoalan tai luonnontuotealan ammattitutkinnon tai luontokartoittajan, keruutuotetarkastajan ja riistamestarin erikoisammattitutkinnon. Näyttötutkintoperusteinen koulutus on pääasiassa aikuisille suunnatttua koulutusta. Vuonna 2007 luonto- ja ympäristöalan toisen asteen koulutusta uudistetaan niin sisällöllisesti kuin tutkintonimikkeitäkin. Erityisesti luontoalan tutkintonimikkeet ja koulutusohjelmat muutetaan paremmin palvelemaan työelämän tarpeita ja kuvaamaan koulutuksen tuottamaa osaamista.

Asiasanat: luonto, ympäristö, opetus, ammatillinen koulutus

\section{Luonto- ja ympäristöala Suomessa}

Ympäristönhoitajien työllisyystilannetta on vaikea selvittää. Työllisyystilanteesta ei ole saatavilla kattavaa aineistoa. Ala on vielä uusi ja ympäristönhoitoon liittyviä töitä varmasti on, mutta niistä ei ole vielä muodostunut varsinaisia työpaikkoja. Monenlaisen koulutuksen saaneet tekevät ns. ympäristönhoitotyötä. Ensimmäinen ammatillisen peruskoulutuksen osaamistarpeita kartoittanut selvitys valmistui vuonna 2005 (Salmela 2005).

Valtioneuvosto teki 13.2.2003 periaatepäätöksen luonnon virkistyskäytön ja luontomatkailun kehittämiseksi. Toimintaohjelman sisältämillä 30 kehittämistoimella tavoitellaan luontomatkailuun liittyvien työpaikkojen kaksinkertaistamista vuoteen 2010 mennessä. Luontomatkailun kehittämisellä voidaan edistää myös syrjäisten maaseutualueiden säilymistä elinvoimaisina. Toimintaohjelmassa edellytetään, että alan kehittäminen tapahtuu kestävällä tavalla. (Ohjelma luonnon virkistyskäytön ja luontomatkailun kehittämiseksi 2002)

Ohjelmassa korostetaan, että alaa tulee kehittää kysynnän pohjalta. Yritysten kannattavuuden kannalta kysynnän arviointi, seuranta ja tutkimus ovat entistä tärkeämpiä. Palveluja käyttävien ja potentiaalisten asiakkaiden tarpeet tulee tunnistaa ja niitä seurata.

Palveluista on tiedotettava entistä tehokkaammin, minkä tueksi on kehitettävä luonnon virkistyskäyttäjiä ja luontomatkailijoita palvelevia yhteen koottuja viestintä- ja myyntikanavia. 
Ohjelma pyrkii myös tukemaan luontoyrittäjien osaamista suosittelemalla alan valtakunnallisen verkkopalvelun perustamista. Lisätietoa toimintaohjelmasta ja sen sisältämistä kehittämistoimista löytyy internetistä ympäristöhallinnon sivuilta www.ymparisto.fi.

Luonnolla on suuri merkitys sekä ihmisten hyvinvoinnille että Suomen matkailulle. Neljännes Suomen matkailusta on luontomatkailua. Luonnon virkistyskäyttöön ja luontomatkailuun liittyvien työpaikkojen kokonaismäärä vastasi vuonna 2000 noin 32000 henkilötyövuotta. Työpaikoista noin kolme neljäsosaa on kotimaisen ja loput ulkomaisen kysynnän tuottamia. Luonnolla on keskeinen merkitys matkailussa erityisesti Pohjois- ja Itä-Suomessa sekä saaristoalueilla. Luontomatkailun aluetaloudelliset vaikutukset ovat paikoin erittäin merkittävät. Matkailulla on laaja vaikutus monien kuntien talouteen.

Luonnontuotealan työllistävyyden arviointia vaikeuttaa tilastotiedon puuttuminen sekä alan kausiluonteisuudesta johtuva suuri sivutoimisten työpaikkojen määrä. Luonnontuotealan työpaikkojen määrä on arviolta noin 10 000, kun mukaan lasketaan pää- ja sivutoimiset sekä yritysten välilliset luonnontuotealan työpaikat ja kotitalouspoiminta. Luonnontuotealan teemaryhmä arvioi kaupallisen luonnonmarjojen-, sienien ja -yrttien poiminnan työllistäväksi vaikutukseksi noin 2000 - 2200 henkilötyövuotta ja erikoiskeruutuotteiden keruun työllistäväksi vaikutukseksi noin 100 - 200 henkilötyövuotta.

Luonto työllistää

- Poimijoita sesonkiaikana 35 - 50000

- Raaka-aineiden ostajia sesonkiaikana 300

- Elintarvikeyrityksissä ympärivuotisesti 600 henkilöä

- Marjoista vuosityöpaikkoja 1500 - 2000

- Sienistä ja yrteistä vuosityöpaikkoja 500 - 700

- Erikoisluonnontuotteista vuosityöpaikkoja 100 - 200

Sieni- ja yrttialan yritysten ja osuuskuntien määrä on lisääntynyt. Vientivaikeudet ovat vaikuttaneet marjojen ostotoimintaan. Tämä on heijastunut erityisesti marjoja varastoiviin yrityksiin. Osa marjanostajista on lopettanut ostotoimintansa ja osa yrittäjistä harkitsee ostotoiminnan siirtämistä ulkomaille. Luonnontuotealan suurimmissa yrityksissä työpaikkojen määrä on kääntynyt laskuun toiminnan rationalisoinnin ja vientimarkkinoilla heikentyneen kilpailukyvyn vuoksi. Vastaavasti pienyrityksien määrä on kasvanut ja liiketoiminta monipuolistunut, mikä on lisännyt työpaikkoja. Myös muihin keruutuotteisiin liittyvä yritystoiminta on lisääntynyt ja samalla monipuolistanut alan yritysrakennetta. Luonnontuotealalla on yleistä erityisesti moniala- ja osa-aikayrittäjyys.

Marja-alalla toimii noin 400 päätoimista yritystä, joista suurin osa on marjanostajia. Tuoremarjakauppaa tekee $100-200$ yritystä. Suomessa on noin $8-10$ keruuyhtiötä. Pieniä hillonvalmistajia on noin 50, tilaviiniyrittäjiä noin 30 ja mehujen valmistajia yli 50. Pieniä marjojen jalostajia on kaikkiaan noin 150 - 200, kun mukaan otetaan myös erikoistuotteiden valmistajat. Suuria mehu- ja hilloteollisuusyrityksiä on noin 10 ja marjapakasteita valmistaa viidestä kuuteen yritystä. Noin 10 yritystä vie luonnonmarjoja. Tuoremarjakauppaa tekee kaikkiaan 100 - 200 yritystä.

Sienialalla arvioidaan olevan noin 50 - 100 päätoimista yritystä, joista monet ovat monialayrityksiä. Sienialalla on hyvin paljon pieniä yrityksiä. Yritykset jakaantuvat kolmeen ryhmään. Tuoresieniä vastaanottavia ja pienimuotoista jalostusta harjoittavia yrityksiä on eniten Pohjois-Karjalassa. Teollista jatkojalostusta tehdään Etelä-Suomessa, jossa täyssäilykkeitä valmistaa kolme yritystä. Suolasienien ja kuivattujen sienien sekä sienipakasteiden valmistajia on useita. Merkittävimpiä sienten pakastajia ovat italialaissuomalaiset yritykset. Sieniä vievien suomalaisten yritysten määrä on pieni. Muutamia yrityksiä on mukana yhteisyrityksissä Baltian maiden ja Valko-Venäjän sienikaupassa.

Yrttiyrityksiä on tasaisesti eri puolilla Suomea. Koska yrttiala on Suomessa vielä varsin nuorta, monet yrttejä hyödyntävät yritykset ovat vasta aloittamassa toimintaansa. Yrttejä kerääviä, viljeleviä ja 
jatkojalostavia yrityksiä on noin 100, joista noin 20 käyttää suomalaisia luonnonyrttejä. Suurin osa yrttituotteista on yhä ulkomaista alkuperää. Lisäksi rohdos- ja erityisvalmisteiden sekä yrttikosmetiikan valmistajia ja/tai maahantuojia on noin 20, joista suurin osa käyttää ulkomaisia viljeltyjä yrttejä. Noin 100 yritystä on keskittynyt muihin keruutuotteisiin. Eniten on jäkälään, pettuun, mahlaan, tervaan, turpeeseen ja tupasvillakuituun perustuvaa yritystoimintaa.

Porotalous on tärkeä elinkeino pohjoisimmassa Suomessa. Poronhoitoalue käsittää pohjoisimman Suomen. Poronomistajien määrä on noin 5 000. Poronhoitovuonna 2006/2007 eloporojen määrä oli yhteensä 196567 poroa. Näistä pohjoisella poronhoitoalueella oli $64 \%$ ja eteläisellä alueella $36 \%$. Keskimääräinen karjakoko oli 133 poroa/tila. Poroa tuotetaan liki 3 milj. kg/vuosi ja sen tuotannon arvo on noin 22 milj. euroa.

\section{Mitä on luontoyrittäjyys?}

Luontoyrittäjyys on luonnon antimiin ja elämyksiin perustuvaa vastuullista yrittäjyyttä. Yritykset ovat tyypillisesti pienyrityksiä. Alalla on kasvava taloudellinen merkitys, sillä ympäristö- ja hyvinvointiarvot korostuvat tulevaisuudessa. Luonnolla on merkittävä rooli alan tuotteissa ja palveluissa.

Luontoyrittäjyys on hyvin monitahoista. Sen osa-alueita ovat esimerkiksi luontomatkailu, maaseutumatkailu ja ohjelmapalvelut. Se kattaa luonnontuotealan, jossa hyödynnetään luonnonmarjoja, sieniä, yrttejä ja erikoisluonnontuotteita. Luontoyrittäjyyteen kuuluu myös puun jatkojalostus eri muodoissaan (esimerkiksi puusepänala, käsityöyrittäjyys). Luontoyrittäjyys on myös riistan, kalojen ja rapujen jatkojalostusta, turpeen ja muiden maaperätuotteiden hyödyntämistä ja tuotteistamista sekä veden, lumen ja jään hyödyntämistä. Kasvava osa-alue on myös luonto- ja maisemapalvelut sekä luontoalan koulutus- ja konsultointipalvelut.

Luontoyrittäjän perustutkinnon voi suorittaa kuudessatoista ammatillisessa oppilaitoksessa. Osa oppilaitoksista onkin profiloitunut kouluttamaan johonkin edellä mainittuun osa-alueeseen. Vahvan luonnontuntemuksen lisäksi luontoyrittäjältä vaaditaan asiakaspalvelua, kielitaitoa, yhteistyötaitoja ja verkottumista, tuotekehitystä sekä ennen kaikkea yrittäjämäistä asennetta ja taitoa.

\section{Ympäristönhoitajat yhä tuntematon ammattiryhmä}

Ympäristönhoito on kaupunkien, taajamien ja maaseudun ympäristön huoltoa sekä maa- ja metsätalouden, teollisuuden ja yritysten ympäristön hoitotehtäviä. Ympäristönhoidon työtehtävien osaalueita ovat esimerkiksi vesihuolto, vesistöjen kunnostus ja hoitotyöt, maa-ainesten otto ja maaperän kunnostus, kiinteistöjen materiaalivirtojen hallinta, energiahuolto, ympäristöterveys tai elinympäristöjen hoito, metsien monikäytön tehtävät sekä ulkoilureittien suunnittelu ja rakentaminen.

Kierrätys ja jätteiden käsittelytehtävät mielletään yleisimmin ympäristönhoitajan tehtäviin. Työt ovat kuitenkin paljon monipuolisempia. Esimerkiksi luonnonhoitopalvelut soveltuvat hyvin ympäristönhoitajan toimenkuvaan. Niitä ovat vesikasvien niitto, perinnebiotooppien hoito, lintuvesien hoito, ruovikon niitto ja laidunnus, käsityönä tehtävä puiden poisto mm. lehdoissa, vesakon poisto, maaperän köyhdytys, kulotus, rantojen raivaus, roskien ja uppopuiden poisto, roskakalan pyynti, pienten jokien entisöinti, soiden ennallistaminen, tiepiennarten niitto, tienvarsien maisema- ja kulttuurikohteiden hoito, suojavyöhykkeiden hoito ja niitto, laskeutusaltaiden rakentaminen ja kunnostus, uhanalaisten lintu- ja kasvilajien elinympäristöjen hoito, pesimäpaikkojen rakentaminen, riistanhoito (kosteikkojen ja riistapeltojen teko, elinympäristöjen kunnostus, talviruokinta, pienpetopyynti, riistakantojen seuranta ja säätely sekä riistarakenteiden teko ja huolto yms.). 
Ympäristöhoitajan työtehtäviä, joita voi nimittää luontopalveluiksi, ovat esimerkiksi luontoreittien ja urien hoito ja huolto, nuotiopaikkojen ja muiden rakenteiden teko ja huolto, reittien ja luontokohteiden jäte- ja puuhuolto, voimalinjojen raivaukset, hoito- ja käyttösuunnitelmien laadinta, kasvillisuuden ja alueiden kehityksen tarkkailu, luontoselvitykset, valvontatyöt, opastustyöt ja muu asiakaspalvelu, talviliikuntapaikkojen yms. perustaminen ja hoito, tienvarsien raivaus, paikallisten ja vapaa-ajan asukkaiden polttopuuhuolto ym. palvelut, talvikunnossapitotyöt, loma-asuntojen ympäristönhoito ja tievarsien hoito, mökkitalkkaritoiminta, ongelmapuiden kaadot, hevosmetsurityöt, vanhojen työmenetelmien säilyttäminen, työnjohtopalvelut, hirvivaara-alueitten erityiskäsittely ja muu liikenneturvallisuuden parantaminen, tieisännöinti.

Valitettavasti vielä osalle työnantajista toisen asteen koulutuksen tuottama ympäristöalan ammattiosaaminen on tuntematonta. Ympäristönhoitajien työllistymistä selvittäneen raportin mukaan korkeakoulututkinnon suorittaneet vievät työpaikkoja tehtävistä, jotka soveltuisivat paremmin perustutkinnon suorittaneelle. Suunnitteilla onkin kampanja, jossa ympäristönhoitoon liittyvistä ammateista kerrotaan sekä työnantajille että nuorille ammatinvalintaa suunnitteleville peruskoululaisille.

\section{Maisemanhoito ammattina}

Maaseudun kehittämisohjelmaan vuosille 2007-2013 kuuluvan ympäristötuen yleistavoitteena on tuotannon harjoittaminen nykyistä pienemmällä ympäristökuormituksella. Samalla pyritään turvaamaan maatalouden luonnon monimuotoisuus ja kulttuurimaisemien säilyttäminen. Tämän tavoitteen saavuttamiseksi ympäristöhoidon ammattilaiset voivat tarjota maisemanhoitopalveluja.

Maisemanhoitopalveluja ovat esimerkiksi viheralueiden ja teiden varsien niitot (viherympäristöurakointi), raivaukset, laidunnus, lanaukset, maisemapeltojen perustaminen ja hoito, luontokohteiden hoito, hoitosuunnitelmien laadinta, maisemainventoinnit, muinaisjäännösten hoitotyö, muinaisjäännösten kunnon tarkkailu, perinnerakennelmien teko ja kunnostus, maisemaa rumentavien rakennusten purku, putki- ja sähkölinjojen maisemointi, soramonttujen maisemointi, vanhojen rakennusten ja rakenteiden kunnostus, kylämaisemien hoito, tiemaisemien hoito, levähdyspaikkojen maisemanavaus sekä energiapuun korjuu maisema-alueilta. Työt soveltuvat hyvin maatalouden liitannäiselinkeinoksi tai vaikkapa maatalouden harjoittamisesta luopuneelle.

Maaseutupolitiikanyhteistyöryhmä YTR on myös panostanut maisemapalvelujen kehittämiseen perustamalla luonto- ja maisemapalveluiden teemaryhmän. YTR on valtioneuvoston asettama yhteistyöelin, jonka tehtävänä on parantaa maaseudun elinvoimaisuutta.

\section{Luonto- ja ympäristöopetus uudistuu}

Luonto- ja ympäristöalan toisen asteen perustutkintoa koskeva uudistustyö on juuri käynnistynyt. Luonto- ja ympäristöalalle tehdään muutoksia ja uudistuksia nykyisiin koulutusohjelmiin. Ympäristönhoidon koulutusohjelma säilyy nykyisellään. Tutkintoon tehdään ainoastaan sisällöllisiä tarkistuksia, jotta tutkinto vastaisi paremmin työelämän vaatimuksia.

Sen sijaan luontoalan koulutusohjelmat uudistetaan. Nykyistä luontoyrittäjä -tutkintonimikettä pidetään selvitysten mukaan vieraana erityisesti nuorten keskuudessa. Niinpä luontoalan koulutusohjelma "paloitellaan" kolmeen eri tutkintonimikkeeseen. Tilalle on tulossa ensinnäkin luonto-ohjaajan tutkinto, joka suuntautuu elämysmatkailuun. Luonnonvara-tuottaja puolestaan erikoistuu tuotteistamaan luonnosta erityyppisiä tuotteita - olivatpa ne sitten syötäviä, käyttöesineitä tai koristeita. Aivan uusi avaus tutkintoon tehdään, kun kolmannesta koulutusohjelmasta voi valmistua luonto- ja ympäristökasvattajaksi. Luonto- ja ympäristökasvattajasta kaavaillaan tutkintoa, jossa yhdistyvät luonto- ja hoiva-ala. Siinä luonto tavalla tai toisella hoitaa tai edistää ihmisen hyvinvointia. 
Luontaistalousyrittäjän tutkinto nimikkeestä luovutaan. Sen sisältämät opintokokonaisuudet sisällytetään uusiin koulutusohjelmiin. Porotalousyrittäjä säilyttää asemansa ainutlaatuisuudellaan. Vain sisällöllisiä tarkistuksia tehdään.

Luonto- ja ympäristöalan perustutkinnon päivittämiseen on asetettu koulutuksen järjestäjien edustajista koottu työryhmä. Sitä ohjaa laajempi ohjausryhmä, jossa on edustettuna työelämän, opettajien ja opiskelijoiden ja eri järjestöjen edustama monipuolinen työryhmä. uudet päivitetyt opetussuunnitelmat valmistuvat niin, että koukutuksen järjestäjät voivat ottaa ne käyttöön vuonna 2010 alkavassa koulutuksessa.

Opetussuunnitelman etenemistä voi seurata internetistä sitä varten perustetulle wikille ja blokille. Ne löytyvät seuraavista osoitteista:

http://luova.wikispaces.com/

http://luonnonvara.blogspot.com/

\section{Kirjallisuus}

OPM 2006. Maatilatalouden koulutuksen kehittämisstrategian, 18/2006, Opetusministeriön muistioita OPH 2005. Luonnonvara- ja ympäristöalan ammatillisen peruskoulutuksen kehittämisohjelma, Opetushallituksen moniste 14/2005.

Suvi Salmela, 2005. Luonto- ja ympäristöalan osaamistarveselvitys, 27/2005, Opetushallitus. 